\title{
KOALISI MASYARAKAT SIPIL DALAM ADVOKASI KEBIJAKAN RELOKASI WARGA TAMBAKREJO KOTA SEMARANG
}

\author{
Muhammad Syofii ${ }^{1}$, Laila Kholid Alfirdaus ${ }^{2}$ \\ Mahasiswa Ilmu Politik Universitas Diponegoro ${ }^{1}$ \\ Dosen Departemen Politik dan Pemerintahan Universitas Diponegoro ${ }^{2}$ \\ Email: m.syofii@gmail.com¹, laila.kholid.alfirdaus@gmail.com²
}

\begin{abstract}
Abstrak
Kebijakan pembangunan normalisasi Banjir Kanal Timur (BKT) Kota Semarang tidak sepenuhnya berjalan lancar karena harus berhadapan dengan pemukiman warga di bantaran sungai. Selain itu pembangunan untuk mengatasi masalah fisik, namun kurang memperhatikan aspek sosial dan ekonomi warga justru menghadirkan permasalahan baru. Kondisi tersebut mendorong aktivisme warga terdampak bersama organisasi masyarakat sipil untuk melakukan advokasi kebijakan. Studi ini bermaksud untuk menjelaskan advokasi politik yang dilakukan koalisi masyarakat sipil di Kota Semarang bersama warga Tambakrejo atas kebijakan relokasi. Studi dilakukan dengan menggunakan metode kualitatif melalui wawancara aktor pendamping, dokumentasi dan observasi. Hasil dalam penelitian menununjukkan advokasi secara koalisi menjadi kunci hadirnya berbagai strategi karena akumulasi sumberdaya masing-masing organisasi yang mampu bekerjasama daripada berkompetisi. Selain itu kemampuan aktor koalisi masyarakat sipil dalam melakukan relasi politik kepada pemangku kebijakan menjadi kunci untuk mengubah kebijakan yang bersifat teknokratis.
\end{abstract}

Kata Kunci:

Koalisi Advokasi, Kebijakan Relokasi, Tambakrejo

\begin{abstract}
The development policy of East Flood Canal (BKT)in Semarang City did not work accordingly purposes because it had to deal with settlements along the river banks. In addition, expansion to overcome physical problems, but not focusing enough to the social and economic aspects of society, otherwise emerged new obstacles. These conditions encourage the activism of affected citizens with community of civil society to advocate for policies. This study intended to explain the political advocacy carried out by the civil society coalition in the city of Semarang with the residents of Tambakrejo over the relocation policy. A qualitative method was conducted in this study through interviewing the accompanying actors, documentation and observation. The results of the study showed that coalition advocacy was the key to the presence of various strategies because of the accumulation of resources of each organization that was able to work together rather than compete. In addition, the ability of civil society coalition actors in conducting political relations with policy stakeholders was the key to changing technocratic policies.
\end{abstract}




\author{
Keywords: \\ Advocacy Coalition, Relocation Policy, Tambakrejo
}

\title{
Pendahuluan
}

Artikel ini berusaha untuk menjelaskan upaya koalisi organisasi masyarakat sipil di Kota Semarang dalam mempengaruhi kebijakan. Adapun kebijakan yang dimaksud yaitu kebijakan merumahkan kembali atau relokasi warga terdampak proyek pembangunan normalisasi Banjir Kanal Timur (BKT) Kota Semarang. Upaya tersebut dalam literatur politik sering dimaknai sebagai advokasi, yang umumnya dilakukan organisasi masyarakat sipil. Artikel ini akan berfokus pada proses dan dinamika politik dalam advokasi kebijakan.

Pemerintah Kota Semarang melakukan relokasi terhadap pemukiman warga Tambakrejo, Kelurahan Tanjungmas sebagai dampak dari proses pembangunan sungai BKT Kota Semarang. Rencana pembangunan tersebut sudah termaktub dalam dokumen Rencana Pembangunan Jangka Menengah Nasional (RPJMN) 2014-2019. ${ }^{1}$ Normalisasi BKT Kota Semarang merupakan proyek nasional di bawah Kementerian Pekerjaan Umum dan Perumahan Rakyat (PUPR), yang dijalankan oleh Balai Besar Wilayah Sungai (BBWS) Pemali-Juana dan bekerjasama dengan Pemerintah Kota Semarang. Salah satu daerah pekerjaan tersebut berada di Kecamatan Semarang Utara, dengan masyarakat terdampak langsung warga Tambakrejo. Hal tersebut sebagai konsekuensi pemukiman warga Tambakrejo berlokasi di samping muara sungai yang berbatasan langsung dengan laut. Melalui proyek normalisasi sungai tesebut, relokasi akan dilakukan terhadap 2.172 warga baik huniannya atau usahanya. Rincian dari korban tersebut tediri dari 1374 pedagang kaki lima, 621 petak hunian, 45 lebih dari satu hunian, 38 fasilitas umum, 94 bangunan lainnya. ${ }^{2}$

Kebijakan relokasi terhadap warga Tambakrejo, sesuai dengan surat edaran yang diterima oleh warga akan dipindahkan ke Rusunawa Kudu yang berlokasi di Kecamatan Genuk dengan jarak kurang lebih 10 Kilometer. Kondisi demikian, justru memunculkan

\footnotetext{
${ }^{1}$ Kementerian Perencanaan Pembangunan Nasional/Badan Perencanaan Pembangunan Nasional, Rencana Pembangunan Jangka Menengah Nasional (RPJMN) 2015-2019: Buku III Agenda Pembangunan Wilayah (Jakarta:BAPPENAS, 2015), h. 7-50.

${ }^{2}$ Kementerian Pekerjaan Umum dan Perumahan Rakyat/Balai Besar Wilayah Sungai PemaliJuana Provinsi Jawa Tengah, Analisis Dampak Lingkungan Hidup (ANDAL) Rencana Pembangunan Pengendalian Banjir di Kanal Banjir Timur Kota Semarang, Provinsi Jawa Tengah (2018), h. 1-18.
} 
masalah baru bagi warga yang bermata pencaharian sebagai nelayan. Bagaimanapun juga kawasan Tanjungmas merupakan wilayah pesisir di Kota Semarang yang mayoritas penduduknya bermata pencaharian sebagai nelayan dengan jumlah 4.888 penduduk, termasuk warga Tambakrejo yang berlokasi terpisah dengan wilayah daratan lainnya. ${ }^{3}$ Selain kondisi pekerjaan yang mengandalkan laut, kondisi kepemilikan aset tanah berada pada posisi yang lemah. Warga tidak memiliki legalitas atas tanah yang mereka tempati. Lahan yang mereka berdiam merupakan aset pemerintah yang ditempati oleh nelayan sejak 1989. Kondisi pemukiman tersebut semakin meluas hingga sekarang dengan pembangunan rumah dan fasilitas umum. Selain itu upaya relokasi tersebut tanpa mempertimbangkan ganti rugi atas bangunan, fasilitas umum yang dibangun, sehingga warga melakukan resistensi atas kebijakan relokasi tersebut.

Praktiknya, upaya penolakan relokasi ke Rusunawa Kudu tidak mampu dilakukan secara sendiri oleh warga Tambakrejo, karena selama ini mereka belum memiliki pengalaman advokasi. Atas kondisi tersebut perwakilan warga Tambakrejo dan juga sebagai ketua Rukun Tetangga (RT), Rohmadi pada Februari 2018 meminta bantuan ke organisasi masyarakat sipil yaitu Pattiro Semarang. Dalam perjalanan advokasi, Pattiro Semarang merasa advokasi tidak dapat dilakukan sendiri, mengingat kasus yang dihadapi bukan hanya terkait kebijakan publik namun juga terkait hukum, dengan begitu menggandeng organisasi lain untuk melakukan advokasi bersama sebagai pilihan. Advokasi yang dilakukan secara berkoalisi tersebut terdiri dari berbagai organisasi yang memiliki latar belakang berbeda-beda. Selain Pattiro Semarang yang memiliki latar belakang advokasi pelayanan publik dan kebijakan publik, terdapat Lembaga Bantuan Hukum (LBH) Semarang yang memiliki latar belakang advokasi Hak Asasi Manusia dan perlindungan hukum. Organisai lain yang juga turut vokal yaitu Guyub Taman Budaya Raden Saleh (TBRS) yang selama ini memiliki latar belakang advokasi melalui seni. Beberapa organisai dan kelompok lain yang turut hadir yaitu kelompok mahasiswa, akademisi dan organisasi masyarakat sipil dengan fokus perlindungan anak dan perempuan.

Advokasi yang dilakukan sejak awal 2018 berjalan penuh dinamika. Warga yang didampingi oleh koalisi masyarakat sipil terjadi perpecahan kehendak, di mana terdapat

\footnotetext{
${ }^{3}$ Badan Pusat Statistik Kota Semarang, Kecamatan Semarang Utara dalam Angka 2019 (Kota Semarang: BPS, 2019), h. 16.
} 
kelompok yang bersedia direlokasi ke Rusunawa Kudu. Namun demikian, koalisi masyarakat sipil tetap melakukan pendampingan terhadap warga yang tetap bertahan di pemukiman Tambakrejo, yang berjumlah 96 kepala keluarga. Berbagai aktivitas advokasi dilakukan melalui pembagian kerja advokasi sesuai kapasitas dan kemampuan lembaga dilakukan baik untuk memfasilitasi kebutuhan warga Tambakrejo. Beberapa aktivitas tersebut yaitu sebagai aktor intermidiator dengan pemerintah, melobi pemerintah, menggalang bantuan dari lembaga pemerintahan pusat dan masyarakat, serta memperkuat sumber daya koalisi advokasi. Berbagai upaya yang dilakukan koalisi masyarakat sipil bersama warga Tambakrejo membuahkan kesepakatan perdamaian pada Desember 2018, di mana warga Tambakrejo dapat bertempat tinggal di Kali Mati yang sampai saat ini masih dalam proses pengurukan.

Praktik proses advokasi melalui kesepakatan perdamaian tersebut tidak cukup untuk mengatasi masalah. Hal tersebut karena pemerintah melakukan penggusuran paksa atas pemukiman warga Tambakrejo pada Mei 2019, meskipun pemukiman yang dijanjikan belum tersedia. Kondisi demikian menjadikan masyarakat sipil hadir lebih intens dalam advokasi. Koalisi masyarakat sipil hadir dalam upaya menggagalkan penggusuran paksa yang dilakukan. Setalah penggusuran paksa tidak dapat terbendung, masyarakat sipil hadir dalam upaya melobi pemangku kebijakan, supaya kesepakatan perdamaian tetap dijalankan. Akhirnya perjalanan advokasi membuahkan hasil dengan adanya kesepakatan kembali ke kesepakatan awal dan BBWS harus menyiapkan hunian sementara serta Pemkot Semarang menyediakan kampung deret. Kondisi demikian menunjukkan keberadaan organisasi masyarakat sipil mampu berfungsi sebagai alat bagi warga negara untuk terlibat dalam urusan publik. ${ }^{4}$ Dengan demikian, tulisan ini hendak meninjau proses dan kompleksitas koalisi masyarakat sipil dalam advokasi kebijakan relokasi warga Tambakrejo, Kelurahan Tanjungmas pada proyek normalisasi BKT Kota Semarang.

\section{Masyarakat Sipil dan Advokasi Kebijakan}

Definisi yang diberikan oleh beberapa akademisi, menjelaskan advokasi sebagai aktivitas politik. Advokasi sebagai aktivitas untuk memengaruhi kebijakan sebagai

\footnotetext{
${ }^{4}$ Joseph P. Zompetti, "The Role of Advocacy in Civil Society" dalam Argumentation: An International Journal of Reasoning, Vol. 20 (2006), h. 180.
} 
bagian integral dari politik baik secara langsung maupun tidak langsung ${ }^{5}$ yang merepresentasikan bentuk partisipasi antara warga negara dengan pengambil kebijakan. ${ }^{6}$ Advokasi dilakukan terhadap individu maupun kelompok yang tidak mampu mewakili kepentingannya dalam ranah politik kebijakan. Pandangan lain disampaikan Aseem dan Mary yang melihat proses advokasi semacam perusahaan khusus dalam pasar kebijakan yang memiliki hambatan dan persaingan, sehingga membuka peluang untuk berkompetisi atau berkolaborasi di antara aktor. ${ }^{7}$

Advokasi sebagai aktivitas politik, mensyaratkan kecerdikan aktornya dalam memengaruhi kebijakan dengan berbagai aktivitas. Mulai dari lobi politik sampai dengan dukungan massa, merupakan gambaran sejauh mana organisasi masyarakat sipil dapat bergerak dan berkreasi. Gen dan Wreight memadukan literatur terkait aktivitas advokasi yang disebut sebagai model logika advokasi. Dalam model tersebut berbagai aktivitas advokasi dapat berupa mobilisasi publik, tekanan publik, memengaruhi pembuat kebijakan, perubahan langsung, dan perubahan implementasi kebijakan. ${ }^{8}$ Sedangkan akademisi lain juga memberi gambaran advokasi sebagai aktivitas berputar bagai siklus yang terdiri dari penelitian, pemilihan kebijakan, kampanye, monitoring implementasi, litigasi. Akan tetapi siklus tersebut tidak harus dilakukan secara berurut, dapat juga secara acak. Siklus yang berisi dari berbagai kegiatan advokasi tidak mungkin dapat dilakukan secara sendiri, sehingga berkoalisi sebagai pilihan. ${ }^{9}$

Salah satu kerangka berpikir dalam memahami advokasi koalisi yaitu Advocacy Coalition Framework (ACF). ACF merupakan kerangka pikir yang yang dikembangkanm oleh Sabatier pada 1988 untuk menangani masalah kebijakan publik yang mendesak. Pada mulanya kerangka ini di gunakan untuk mengkaji kebijakan di

\footnotetext{
${ }^{5}$ Aseem Prakash \& Mary K. Gugerty (Eds.), Advocacy Organizations and Collective Action (New York: Cambridge University Press, 2010), h.1.

${ }^{6}$ Elizabeth J. Reid, "Understanding the Word "Advocacy": Context and Use" dalam Elizabeth J. Reid (Eds.), Advocacy and the Policy Process: Structuring the Inquiry into Advocacy (Washington, D.C.: The Urban Institute, 2000), h.1.

${ }^{7}$ Aseem Prakash \& Mary K. Gugerty, Op.Cit., h. 3.

${ }^{8}$ Sheldon Gen \& Amy C. Wreight, "Policy Advocacy Organizations: A Framework Linking Theory and Practice" dalam Journal of Policy Practice, Vol. 12, No.3 (2014), h.182.

${ }^{9}$ Garry D. Bass, "Advocacy in the Public Interset" dalam Essays on Excellence Lessons from the Georgetown Nonprofit Management Executive Certificate Program (Wasington D.C.: Gerogetown University, 2009), h. 5.
} 
bidang energi dan lingkungan di United State of America. ${ }^{10}$ Akan tetapi dalam perkembangannya hingga saat ini kerangka tersebut telah diadopsi dalam berbagai bidang pengetahuan sosial, ekonomi, kesehatan, begitupun juga di terapkan di berbagai negara seperti di Eropa, Asia, Canada, Australia, Amerika Selatan dan Afrika. Selain dapat diterapkan di berbagai daerah, dan berbagai topik, juga dapat diaplikasikan dengan teori kerangka kebijakan lainnya. ${ }^{11}$ Kerangka tersebut dalam hemat Weible dan Sabatier tepat digunakan sebagai lensa untuk memahami dan menjelaskan perubahan keyakinan dan kebijakan ketika ada ketidaksepakatan tujuan dan perselisihan teknis yang melibatkan beberapa aktor dari berbagai tingkat pemerintahan, kelompok kepentingan, lembaga penelitian, dan media. ${ }^{12}$ Begitupun ahli lain, Sewell mengartikan koalisi advokasi sebagai sekelompok orang dari berbagai posisi seperti pejabat, pemimpin kelompok kepentingan, peneliti, dan lain-lain yang berbagi sistem kepercayaan. ${ }^{13}$ Kerangkan koalisi advokasi digunakan mengingat beberapa kelebihan yang dapat menyoroti persoalan kebijakan, di antara kelebihan tersebut ACF mampu menyoroti besar sifat konflik politik dan dapat berlaku untuk struktur pemerintahan, masyarakat budaya, dan bidang kebijakan yang berbeda.

Dalam penjelasan Weible dan Sabatier, komponen dalam ACF terdapat dari 3 hal, yaitu parameter relatif stabil, subsistem kebijakan dan peristiwa eksternal. ${ }^{14}$ Parameter ini bersifat stabil dalam jangka waktu yang lama. Parameter stabil tersebut penting karena membentuk sifat masalah, membatasai sumber daya yang tersedia pada peserta kebijakan, menetapkan peraturan dan prosedur untuk mengubah kebijakan dan mencapai keputusan kolektif, dan secara umum membingkai nilai-nilai yang menginformasikan kebijakan. Dalam struktur ACF, susbsitem kebijakan berisi individuindividu yang ada di dalam subsistem kebijakan dalam memandang suatu permasalan kebijakan menggunakan keyakinan dasar, keyakinan inti kebijakan dan keyakinan

\footnotetext{
${ }^{10}$ Paul A. Sabatier \& Christopher M. Weible, "The advocacy Coalition Framework Innovation and Clarifications" dalam Paul Sabatier (Eds.), Theories of the Policy Process (Boulder,CO: Westview Press, 2007), h. 189.

${ }^{11}$ Christopher M. Weible, Paul A. Sabatier \& McQueen, "Themes and Variations: Taking Stock of the Advocacy Coalition Framework" dalam The Policy Studies Journal. Vol. 37, No. 1 (2009), h. 125.

${ }^{12}$ Christopher M. Weible \& Paul A. Sabatier, "Panduan Kerangka Koalisi Advokasi" dalam Frank Fischer, Gerald J. Miller \& Mara S. Sidney (Eds.), Handbook Analisis Kebijakan Publik:Teori,Politik dan Metode (Bandung: Nusamedia, 2016).

${ }^{13}$ Granville C. Sewell, "Actors, Coalitions, and the Framework Convention on Climate Change". Dissertasi. (Massachutsetts: Massachusetts Institute of Technology, 2005).

${ }^{14}$ Paul A. Sabatier \& Christopher M. Weible, Op.Cit., h. 191.
} 
sekunder. Mereka mampu berhasil ketika dapat menerjemahkan keyakinan inti ke dalam kebijakan sebenarnya. Selain itu untuk meningkatkan peluang kemenangan, pesera kebijakan mencari sekutu dengan keyakinan yang sama dan mengkoordinir tindakan mereka dalam koalisi advokasi. Di sinilah letak relasi kuasa akan terletak dalam mempertahankan kepentingannya. Dalam struktur ACF terdapat komponen peristiwa eksternal yang dapat mempengaruhi subsistem kebijakan. Peristiwa eksternal tersebut penting mengingat mereka sering mengalihkan perhatian publik menjauh dari subsistem kebijakan.

Sumber daya yang dimiliki oleh peserta koalisi menjadi penting, karena memengaruhi strategi dan hasil advokasi. Teori ACF masih memiliki kekurangan terkait penelitian sumber daya tersebut. Sejumlah enam sumber daya koalisi yang disampaikan oleh Sabatier, ${ }^{15}$ oleh peneliti lain hasilnya pun berbeda-beda atas kekuatan sumber daya tersebut. Sumber daya opini publik dalam perjuangan advokasi menjadi sumber daya yang paling kuat untuk memberikan tekanan kepada pemerintah, sehingga kebijakan dapat berubah. ${ }^{16}$ Namun kekuatan tersebut berbeda halnya dalam pandangan yang disampaikan oleh Nohrstedt. ${ }^{17}$ Dalam penelitiannya menunjukkan kewenangan legal formal memiliki kekuatan yang sangat besar dan mengabaikan yang lain. Dengan demikian masih memerlukan banyak penelitian untuk menemukan kekuatan atas sumber daya lainnya.

Meskipun sudah sejak lama teori ACF digunakan, namun dalam berbagai penggunaan memberikan gambaran akan kelebihan dan kekurangannya. ${ }^{18}$ Dalam pandangan Weibel dan Sabatier, kelebihan dari teori ACF yaitu; Pertama, ACF menyediakan lensa alternatif untuk kerangka kerja pembuatan kebijakan secara de facto; Kedua, ACF menyoroti besarnya dan sifat konflik politik; Ketiga, ACF mencakup peran penting informasi ilmiah dan teknis dalam sengketa kebijakan dan politik; Keempat, ACF sangat berlaku untuk struktur pemerintahan, masyarakat budaya, dan bidang kebijakan yang berbeda. Selain kelebihan dari teori tersebut dalam

15 Ibid., h. 201.

${ }^{16}$ Jonathan J. Pierce, “Advocacy Coalition Resources and Strategies in Colorado Hydraulic Fracturing Politics" dalam Society \& Natural Resources: An International Journal, Vol. 29, No.10 (2016), h. 1164.

${ }^{17}$ Daniel Nohrstedt, "Shifting Resources and Venues Producing Policy Change in Contested Subsystems: A Case Study of Swedish Signals Intelligence Policy" dalam The Policy Studies Journal. Vol. 39, No. 3 (2011), h. 481.

${ }^{18}$ Christopher M. Weible \& Paul A. Sabatier, Op.Cit., h. 131. 
membedah masalah kebijakan, terdapat juga kekurangan dalam teori tersebut. Kekurangan yang ada setidaknya ada 3, yaitu; Pertama, ACF akan sulit di terapkan karena untuk memahami konflik politik dan perubahan kebijakan mengasumsikan perspektif satu dekade atau lebih; Kedua, ACF akan kehilangan sebagian manfaat dalam subsistem kebijakan tanpa koalisi yang jelas atau dengan satu koalisi yang dominan; Ketiga, ada beberapa mata rantai yang hilang dalam proses sebab akibat yang digambarkan oleh ACF yang membutuhkan penyelidikan teoretis dan empiris tambahan.

Meskipun ACF sudah banyak digunakan untuk melakukan analisis advokasi kebijakan, namun terdapat beberapa hal yang harus menjadi fokus perhatian dalam penerapannya. Adapun hal tersebut, yaitu; Pertama, fokus pada pengujian dan pengembangan teori ACF; Kedua, menggunakan ACF untuk penelitian perbandingan kebijakan publik; Ketiga, merevisi pembelajaran berorientasi kebijakan; Keempat, mengembangkan peran dari sumberdaya koalisi; Kelima, menginvestigasi yang belum tereksplor dalam teori; Keenam, menghubungkan ACF dengan kerangka dan teori lainnya. ${ }^{19}$ Dengan pandangan perkembangan teori ACF tersebut, masih sangat di butuhkan untuk mengkaji dan mengembangkan penggunaan teori ACF.

Sebagai proses politik yang dilakukan secara bersama-sama, koalisi advokasi bukanlah hal mudah untuk mencapai kesepakatan. Kemampuan untuk manajemen sumber daya dan merancang arah strategi harus dimiliki dalam koalisi. Levi dan Murphy juga menekankan kepercayaan organisasi dan kemampuan organisasi membawa kepentingan menjadi pokok tantangan organisasi. ${ }^{20}$ Selain itu advokasi sebagai proses politik koalisi harus mampu untuk meyakinkan para pembuat kebijakan supaya tujuan yang diharapkan berhasil.

Koalisi advokasi menawarkan berbagai keuntungan yang diperoleh, akan tetapi juga perlu mempertimbangkan beberapa dampaknya. Melalui koalisi manfaat akan gabungan organisasi akan memberi kekuatan sehingga mampu meningkatkan pengaruh

\footnotetext{
${ }^{19}$ Christopher M. Weible, dkk., "A Quarter Century of the Advocacy Coalition Framework: An Introduction to the Special Issue" dalam The Policy Studies Journal. Vol. 39, No. 3 (2011), h. 354.

${ }^{20}$ Margaret Levi \& Gillian H. Murphy, "Coalition of Contention: The Case of the WTO Protest in Seattle" dalam Political Studies, Vol. 54 (2006), h. 668.
} 
politik ketika dihadapkan pada lawan. ${ }^{21}$ Akan tetapi bersatunya organisasi tersebut akan menghilangkan beberapa kekuasaan atas pengambilan keputusan. Keputusan akan advokasi akan dibentuk secara bersama dan menghilangkan kediktatoran, sehingga hak veto tidak akan ada dalam koalisi karena monimnya sumberdaya maisng-masing aktor. $^{22}$

Organisasi masyarakat sipil yang ada saat ini tentunya memiliki perbedaan karakteristik. Perbedaan tersebut baik dari jenis advokasi sampai dengan perbedaan ideologi. Bergabungnya berbagai organisasi dalam koalisi tentunya memiliki tantangan khusus terhadap perbedaan ideologi dan pandangan yang berpengaruh terhadap strategi dan kebijakan advokasi. ${ }^{23}$ Namun perbedaan ideologi tersebut juga berpengaruh terhadap munculnya berbagai strategi yang dapat dilakukan. Akan tetapi tantangannya dapatkah koalisi tersebut bekerjasama atau berkompetisi. ${ }^{24}$

\section{Metode Penelitian}

Penelitian dalam tulisan ini menggunakan metode kualitatif terhadap koalisi masyarakat sipil. Penelitian didukung dengan wawancara, dokumentasi serta observasi yang dilakukan oleh penulis selama proses advokasi terjadi mulai awal 2018. Wawancara dilakukan terhadap aktor kunci dari masing-masing aktivitas untuk mendukung terjadinya perubahan kebijakan. Tentunya aktor tersebut perwakilan advokasi dari masing-masing organisasi masyarakat sipil yang terlibat dalam advokasi. Merefleksikan dari hasil penelitian, paper ini melihat bagaimana koalisi masyarakat sipil menjalani relasi kuasa dengan pembuat kebijakan dalam upaya mengubah kebijakan.

\section{Pemukiman Tambakrejo, Kebijakan Relokasi dan Kondisi Warga}

Hadirnya pemukiman warga Tambakrejo tidak dapat dilepaskan dari latar belakang pekerjaan warga sekitar sebagai nelayan. Pemukiman tersebut muncul mulai

${ }^{21}$ Dara Z. Strolovitch, Affirmative Advocacy: Race, Class, and Gender in Interest Group Politics (Chicago: Univesity of Chicago Press, 2007), h. 178.

${ }_{22}$ William A. Gamson, "A Theory od Coalition Formation" dalam American Sociological Review, Vol. 26, No. 3 (1961), hal. 374.

${ }^{23}$ Steven E. Barkan, "Interorganizational Conflict in the Southern Civil Rights Movement" dalam Sociological Inquiry. Vol. 56, No. 2 (1986), h. 204.

${ }^{24}$ Suzanne Staggenborg, "Coalition Work in the Pro-Choice Movement: Organizational and Environmental Opportunitiesand Obstacles" dalam Social Problems, Vol. 33, No. 5 (1986), h. 388. 
tahun 1989 yang ditempati sekitar 20 kepala keluarga nelayan dan pemilik tambak. Selanjutnya di sekitar tahun 1990-an bertambah menjadi 50 kepala keluarga, dan sudah mulai mendapatkan kartu tanda penduduk, kartu keluarga dan akta kelahiran dengan alamat RT 05 RW 16 Kelurahan Tanjungmas, Semarang Utara. Sampai tahun 2000-an dibangunlah berbagai fasilitas umum seperti jalan, jembatan, mushola dan Taman Pendidikan Al Quran (TPQ) hingga tahun 2018 terdapat sekitar 160 kepala keluarga menempati wilayah tersebut. Meskipun pada awalnya warga yang tinggal di wilayah tersebut yaitu nelayan dari berbagai lokasi seperti Kampung Cilosari, Kelurahan Tambakrejo, Kelurahan Tanjungmas dan pendatang dari Jepara serta Demak, namun lambat laun menyebar ke berbagai profesi. Nyatanya beberapa penduduk yang bekerja sebagai buruh pabrik, supir dan lainnya juga tinggal di wilayah tersebut. Meskipun tanah yang mereka tempati sebagai tanah pemerintah, namun untuk mendapatnya mereka harus membeli seharga 1 sampai 5 juta ke pendatang awal.

Secara geografis, perkampungan Tambakrejo berada di posisi yang kurang menguntungkan. Posisi perumahan warga dibuat menjadi dua deret dengan dipisahkan jalan kecil perkampungan. Di belakang pemukiman warga sebelah kanan berbatasan langsung dengan sungai BKT Kota Semarang dan di belakang pemukiman warga sebelah kiri berbatasan langsung dengan Kali Banger/Kali Mati. Selain itu di kedua sisi yang lain paling ujung kampung langsung berbatasan dengan Laut Jawa, serta awal perumahan kampung langsung berada di bawah jembatan flyover. Dengan posisi tersebut, maka perkampungan Tambakrejo cukup terpisah dengan pemukiman lain di Kelurahan Tanjung Mas, sehingga cukup sulit untuk dijangkau dari jalan utama kelurahan. Pemukiman yang berbatasan langsung dengan laut dan sungai, menyebabkan rob sebagai pemandangan lumrah yang menerjang perkampungan. Selain itu, lokasi tempat tinggal warga, mayoritas penduduk bekerja sebagai nelayan dengan perahu kecil. Rob yang terjadi di perkampungan Tambakrejo terjadi 4 sampai 5 tahun terahir, sehingga mereka juga melakukan peninggian bangunan.

Kebijakan relokasi warga Tambakrejo muncul sebagai akibat dari proyek pembangunan normalisasi BKT Kota Semarang. Proyek tersebut merupakan proyek dari pemerintah pusat di bawah Kementerian Pembanunan Umum dan Perumahan Rakyat yang didukung oleh Pemerintah Kota Semarang. Program tersebut telah dirancang dan termuat dalam RPJMN 2015-2019. Dalam rangka mendukung kebijakan 
pemerintah pusat, Pemerintah Kota Semarang berkomitmen untuk mendukung proyek tersebut. Dalam Rencana Pembangunan Jangka Menengah Daerah (RPJMD) Kota Semarang (Perda No. 6 tahun 2016) dan perubahan RPJMD 2016-2021. Proses dilaksanakan berdasar Keputusan Menteri Pekerjaan Umum dan Perumahan Rakyat No. 24/KPTS/M/2016 tentang Rencana Pengelolaan Seumber Daya Air Wilayah Sungai Jeratun Seluna. Atas rencana pembangunan tersebut, didukung oleh Pemerintah Kota Semarang, dengan surat kesesuaian tata ruang kegiatan pembangunan pengendalian BKT Kota Semarang melalui surat Bappeda No. 045:/1820 tanggal 13 Maret 2017.

Dalam dokumen Analisis Mengenai Dampak Lingkungan (AMDAL), kebijakan normalisasi banjir kanal timur dilaksanakan melalui keputusan menteri Pembangunan Umum dan Perumahan Rakyat no. 24/KPTS/M/2016 berdampak ke seluruh bangunan dan hunian di sepanjang sungai BKT Kota Semarang. Terhadap pemukiman warga, kebijakan memukimkan kembali atau relokasi sebagai solusi yang diberikan pemerintah. Relokasi pemukiman warga terdampak pembangunan akan dilakukan di rusunawa. Rusunawa yang tersedia di Kudu dan Trimulyo Kecamatan Genuk dan Rawasari Kecamatan Tembalang.

Kondisi warga yang bermata Bpencaharian sebagai nelayan, menolak upaya relokasi tersebut, karena menjauhkan dengan laut. Sehingga terdapat ketegangan antara warga dengan pemerintah. Pasalnya relokasi akan dilakukan di Rusunawa Kudu yang berjarak sekitar 10 kilometer dari laut. Gejolak awal dimulai saat pemerintah Kota Semarang mengeluarkan surat untuk relokasi yang membuat warga terusik. Mengingat ketidakmampuan mereka untuk melakukan advokasi supaya tetap bertahan di Tambakrejo. Perwakilan warga sekaligus ketua Rukun Tetangga (RT) yaitu Rohmadi meminta bantuan ke Pattiro Semarang, yang kemudian secara bersama-sama mengajak organisasi lain seperti LBH dan Guyub TBRS untuk melakukan advokasi bersama.

Berbagai upaya untuk lobi dan kampanye dilakukan supaya warga tetap bertahan mulai Februari 2018. Akan tetapi dalam perjalannya, tidak seluruh warga setuju dengan upaya tersebut. Kekuatan warga pecah menjadi kelompok yang tetap bertahan sekitar 97 kepala keluarga yang bermata pencaharian sebagai nelayan, namun lainnya memilih berpindah ke Rusunawa Kudu. Melalui hasil wawancara mereka yang memilih pindah memang tidak memiliki ketergantungan dengan laut karena tidak bekerja sebagai nelayan. 
Akan tetapi kondisi kekuatan di dalam warga yang pecah tidak memengaruhi untuk berhenti melakukan advokasi. tetap bersama 97 kepala kepala keluarga, advokasi tetap dilakukan dengan berbagai upaya. Melalui berbagai upaya lobi dan mediasi, maka terbentuklah kesepakatan perdamaian antara warga Tambakrejo dengan Pemerintah Kota Semarang. Kesepakatan yang terbentuk pada 13 Desember 2018 tersebut pada intinya warga Tambakrejo dengan jumlah 97 kepala keluarga dapat tinggal di pemukiman yang selama ini mereka tinggali hingga diurugnya Kali Banger untuk mereka dirikan bangunan baru. Dengan begitu warga kembali ke kehidupannya dengan pekerjaan sebagai nelayan dengan menunggu realisasi pengurukan sungai.

Kesepakatan tersebut bukanlah sebagai titik terang dalam advokasi masyarakat sipil. Nyatanya kesepakatan belum dikerjakan sampai akhir, namun penggusuran paksa terjadi ke warga. Kondisi tersebut dimulai dengan datangnya surat BBWS, dengan memperingatkan warga untuk bergegas pindah karena penggusruan rumah warga akan dilakukan. Kondisi tersebut disusul pada hari Jumat 3 Mei 2019, sekitar 600 personel dari Satuan Polisi Pamong Praja (SatpolPP) bersama dengan BBWS dan Camat Semarang Utara memasuki Tambakrejo untuk melakukan penggusuran terhadap pemukiman namun ahirnya mereka menarik diri dengan memperingatkan warga untuk segera pindah. Penggusuran tidak bisa terbendung, tepatnya pada Kamis, 9 Mei 2019 warga tetap tidak pindah, hingga akhirnya terjadi penggusuran.

Penggusuran terhadap pemukiman warga menggunakan alat-alat berat, berakibat luluh lantahnya rumah dan seluruh perabot yang dimiliki. Dalam kondisi tersebut lantas peroblematika yang muncul yaitu pemenuhan terhadap kebutuhan pokok sehari-hari. Dalam masa pengungsian tersebut, untuk memenuhi kebutuhan pangan dan kebutuhan primer lainnya mereka mendapat donasi yang telah digalang berbagai organisasi masyarakat sipil serta mahasiswa. Selain itu mereka mendapatkan donasi dari pemerintah Kota Semarang melalui Dinas Sosial (Dinsos) dan beberapa lembaga lainnya seperti PMII, ACT dan lain-lain. Mekanisme pengelolaan terhadap donasi tersebut dilakukan oleh warga secara bersama. Selain itu donasi yang terkumpul juga digunakan untuk kehidupan warga terdampak.

Upaya lobi yang dilakukan oleh aktor advokasi, mampu menemukan pertemuan multi stakeholder untuk menyelesaikan permasalahan pada Minggu 12 Mei 2019 di Gedung Pemerintah Kota Semarang. Hasil dari pertemuan tersebut di mana akhirnya 
warga akan disiapkan hunian sementara (huntara) berupa bedengan sejumlah 3 unit yang akan dibangunkan BBWS, sedangkan pemerintah Kota Semarang akan menyediakan kampung deret untuk tempat tinggal setelahnya. Sampai bulan Juli 2019, Bedeng terbangun 2 dan 1 lagi baru terbangun di bulan Agustus 2019 melalui proses diskusi.

\section{Perjuangan Koalisi Masyarakat Sipil dan Warga Tambakrejo}

Perjuangan organisasi masyarakat sipil di Kota Semarang dalam advokasi kebijakan relokasi warga Tambakrejo tidak terlepas dari kemampuan dari masingmasing organisasi. Akumulasi sumber daya dari berbagai organisasi yang terlibat menghasilkan berbagai strategi advokasi, baik yang bersifat penguatan organisasi, penguatan jaringan publik maupun jejaring pemangku kebijakan. Berbagai aktivitas yang dilakukan sebagi berikut.

Pertama, pembentukan koalisi (coalition building) advokasi merupakan langkah awal yang dilakukan dalam membantu warga Tambakrejo. Sebagaimana yang diungkapkan oleh Arif dari Pattiro Semarang, koalisi advokasi dilakukan mengingat keterbatasan kemampuan organisasi dalam mengatasi kebijakan relokasi. Perwakilan warga Tambakrejo yang menolak relokasi meminta bantuan Pattiro Semarang yang selama ini memiliki kemampuan di bidang advokasi pelayanan publik, namun tidak memiliki kemampuan pendampingan hukum serta pengumpulan opini publik yang masif. Dengan demikian atas telaah kasus, membangun koalisi menjadi pilihan, bukan hanya saat awal melakukan advokasi, namun selama advokasi berlangsung.

Beberapa organisasi dan aktor yang masuk dalam koalisi advokasi memiliki sumberdaya yang variatif. Setidaknya beberapa aktor yang hadir yaitu dari LBH Semarang, Guyub TBRS, akademisi, kelompok mahasiswa dan lain-lain. Berdasarkan pengamatan penulis dalam proses advokasi beberapa sumberdaya yang ada yaitu LBH Semarang yang memiliki kemampuan telaah dan advokasi kasus hukum berdasarkan bidang lembaga dan jenis advokasi mereka. Selain itu memiliki kemampuan untuk mengkoordinir aksi dalam menggalang dukungan yang selama ini sering dilakukan melalui Aksi Kamisan. Organisasi lain yang tergabung yaitu Guyub TBRS yang memiliki kemampuan penyebaran isu melalui seni dan budaya, serta beberapa anggotanya merupakan jurnalis, sehingga membantu penyebaran isu melalui media 
massa. Selain itu dalam kelompok Guyub TBRS juga memiliki aktor yang memiliki kemampuan lobi politik. Lembaga lain yang juga turut dalam koalisi advokasi yaitu Yayasan Setara yang memiliki fokus terhadap pendampingan anak. Turut dalam koalisi advokasi juga akademisi yang memiliki keahlian ilmu lingkungan dan arsitektur. Hal tersebut dilakukan guna untuk pengetahuan atas rancangan pembangunan oleh pemerintah supaya sesuai dengan kebutuhan warga Tambakrejo.

Kedua, setelah membentuk kaolisi advokasi, strategi selanjutnya yang dilakukan oleh koalisi dalam advokasi warga Tambakrejo yaitu mengikat dan mobilisasi publik. Hal tersebut dilakukan dengan tujuan memperbanyak dukungan dan memberi tekanan pada pemerintahm supaya terjadi perubahan kebijakan. Beberapa kegiatan dalam upaya mengikat publik dapat dilihat dari Aksi Kamisan yang dikoordinir oleh LBH Semarang dengan kelompk mahasiswa. Beberapa kali Aksi Kamisan dilakukan dengan mengangkat tema Tambakrejo, baik dengan menghadirkan korban secara langsung ataupun tidak yang dilaksanakan di depan Kantor Gubernur Jawa Tengah. Upaya tersebut dilakukan dengan mengajak kelompok mahasiswa dan juga menyebar pamflet sebelum aksi dilaksanakan. Selain melakukan aksi, upaya untuk mengikat publik dilakukan dengan kampanye kreatif dan mengikat berbagai kelompok seniman dan mahasiswa. Aktivitas tersebut dilakukan oleh Guyub TBRS. Kampanye tersebut dilakukan dengan bertepatan hari-hari penting seperti hari nelayan. Upaya tersebut selain mengikat publik, sebagimana yang diutarakan oleh Adit dari Guyub TBRS juga menguatkan warga dan tidak merasa sendiri.

Ketiga, Selain melakukan upaya mengikat dan mobilisasi publik, hal yang dilakukan koalisi advokasi yaitu mengikat pemerintah. Meskipun tidak semua organisasi memiliki gaya advokasi yang sama dalam berhubungan dengan pemerintah mereka melakukan dengan caranya masing-masing. Sebagaimana dalam advokasi, upaya mengikat pemerintah dilakukan dengan gaya berbeda-beda. Pattiro Semarang, dalam pelaskanaannya melakukan dialog dengan pemerintah Kota Semarang dan melakukan pemetaan terhadap mereka yang masih mampu diajak bernegosiasi, dan Walikota termasuk pihak yang mau diajak berdialog. Selain itu Guyub TBRS, melakukan pendekatan politik tersebut langsung dengan Walikota Semarang dan juga Gubernur Jawa Tengah. Hal tersebut dilakukan mengingat aktor masyarakat sipil dari Guyub TBRS memiliki kedekatan dengan Walikota dalam ikatan pemenangan saat 
Pilkada. Hal ini dikatakan upaya mengikat pemerintah, karena Pattiro Semarang berusaha untuk membuka ruang diskusi dengan mengajak dinas teknis, begitupun aktor Guyub TBRS dengan melakukan komunikasi informal dengan pemangku kebijakan, mengingat mereka memiliki kedekatan dengan pemangku kebijakan baik di Kota maupun Provinsi.

Keempat, untuk memperbanyak dukungan dan penyebaran isu kampanye informasi juga dilakukan oleh koalisi advokasi. Kampanye informasi dilakukan melalui berbagai kegiatan. Sebagaimana yang dilakukan oleh Guyub TBRS kampanye dilakukan melalui pembuatan film, selain itu mendatangkan figur publik seperti Puteri Indonesia, untuk melakukan kampanye publik. Selain itu, bentuk kampanye publik juga dilakukan melalui Aksi Kamisan yang digawangi oleh LBH Semarang dan kelompok mahasiswa serta melakukan safari kampus bersama Pattiro Semarang. Melalui hal tersebut, mahasiswa dari berbagai perguruan tinggi di Kota Semarang turut dalam memberikan bantuan dan dukungan terhadap warga Tambakrejo.

Kelima, upaya advokasi dilakukan melalui monitoring kebijakan. Beberapa bentuk monitoring kebijakan dilakukan salah satunya dalam rangka menagih kewajiban BBWS dan Pemkot Semarang yang tertuang dalam kesepakatan perjanjian. Hal tersebut dilakukan dengan dialog bersama stakeholder dari Pemerintah Kota Semarang dan BBWS untuk pelaksanakaan pembangunan kampung deret dan pembangunan hunian sementara. Sebenarnya monitoring kebijakan dilakukan saat awal advokasi untuk mengetahui desain pembangunan yang dilakukan oleh pemerintah. Hal tersebut salah satunya dilakukan melalui akses informasi sampai pada sengketa melalui Komisi Informasi Provinisi Jawa Tengah, meskipun pada akhirnya dokumen bersifat tertutup.

Perbedaan organisasi yang bergabung dalam koalisi untuk melakukan advokasi tentunya memiliki tantangan tersendiri. Sebagaimana yang disampaikan oleh Nico Wauran dari LBH Semarang, tanggungjawab pendampingan yang dilakukan bukan hanya di Tambakrejo, akan tetapi memiliki tanggunggjawab advokasi di tempat lain yang lokasinya tidak di Kota Semarang, serta tugas lain di kantor. Kondisi demikian tentunya cukup menyita waktu dan mempengaruhi pendampingan yang dilakukan di Tambakrejo. Hal demikian juga disampaikan Amri dari Pattiro Semarang. Imbasnya saat harus ada rapat advokasi tidak semuanya dapat hadir dan hal tersebut berpengaruh 
terhadap pengambilan keputusan yang biasanya ditunda. Kondisi demikian tentunya menjadi kendala dalam pengambilan keputusan dalam advokasi.

Perbedaan ideologi dan gaya advokasi dari masing-masing organisasi juga menjadikan perbedaan dalam menghadapi pemerintah. Kondisi lembaga yang tidak seragam memiliki cara advokasi yang tidak seragam pula. Sebagaimana diperlihatkan oleh Pattiro Semarang, dalam melakukan advokasi tidak selalu dengan menolak untuk berinteraksi dengan pemerintah, sehingga menggunakan cara dialogis dan audiensi menjadi pilihan. Berbeda halnya dengan LBH Semarang dalam melakukan advokasi cenderung menolak berhubungan dengan pemerintah. Kondisi demikian juga tercermin dalam upaya untuk menentukan pilihan Rusun ke warga. Sebagaimana dalam informasi yang disampaikan Amri, informan dari Pattiro Semarang, bahwasannya untuk tawaran Rusun, LBH Semarang menolak keras, akan tetapi Pattiro Semarang mengembalikan pilihan itu ke warga.

\section{Jejaring Politik Koalisi Advokasi Kebijakan}

Advokasi sebagai proses politik dalam kebijakan, tidak bisa dilepaskan dengan hubungan dan jejaring politik aktor advokasi. Bagaimanapun juga, jejaring politik dan kemampuan untuk berhadapan dengan aktor politik menjadi kunci dalam keberhasilan advokasi. Setiap organisasi yang tergabung, memiliki latar belakang organisasi yang berbeda dalam berkomunikasi dengan pemangku kebijakan. Namun demikian, setiap organisasi baik LBH Semarang, Pattiro Semarang dan Guyub TBRS yang tergabung dalam koalisi advokasi memainkan peran politik untuk mencapai tujuan advokasi supaya warga Tambakrejo tidak direlokasi jauh dari laut.

LBH Semarang merupakan salah stau organisasi yang tergabung dalam koalisi advokasi. Selama ini pilihan advokasi yang ditempuh oleh LBH Semarang yaitu berada di luar pemerintah, dengan melakukan penolakan. Meskipun begitu, langkah politis lain diambil oleh LBH Semarang selain menggunakan strategi yang jamak digunakan dalam advokasi. LBH Semarang bersama perwakilan warga dalam usahanya melakukan pengaduan ke Komisi Nasional Hak Asasi Manusia (Komnas HAM). Langkah tersebut diambil, sebagai langkah memperjuangkan hak mereka untuk mendapatkan pemukiman dan hak pekerjaan. 
Langkah politis yang dilakukan LBH Semarang dengan menggandeng Komnas HAM membuahkan hasil. Komnas HAM menindaklanjuti laporan dan turun tangan dalam membantu menyelesaikan perselisihan yang terjadi antara warga Tambakrejo dengan Pemerintah Kota Semarang. Akhirnya melalui usaha tersebut Komnas HAM mampu menjadi mediator di antara warga Tambakrejo, Pemerintah Kota Semarang dan BBWS Pemali-Juana untuk kesepakatan damai yang dicapai pada Desember 2018. Dalam kesepakatan tersebut menunjukkan bahwasanya warga akan dibangunkan kampung deret tidak jauh dari lokasi sebelumnya dan warga akan berpindah setelah tersedia bangunan.

Organisasi lain yang juga melakukan advokasi politik tersebut Pattiro Semarang. Selama ini Pattiro Semarang dalam melakukan advokasi, memang harus berhubungan dengan pemerintah. Hal tersebut dilakukan mengingat visi lembaganya untuk menciptakan good governance, sehingga dengan pemerintah menjadi mitra kritis. Terkait pendekatan politik yang dilakukan, sejak awal Pattiro Semarang yang menjembatani hubungan dengan Pemerintah Kota Semarang dalam kaitannya mendukung warga Tambakrejo. Dalam upayanya, Pattiro Semarang melakukan pemetaan kekuatan di dalam pemerintah untuk melancarkan proses advokasi. Dalam pemetannya didapatkan bahwasannya ada aktor yang tidak setuju seperti Sekretaris Daerah (Sekda) dan camat, namun terdapat juga aktor yang ingin diajak untuk berbicara dan melakukan negosiasi, yaitu Walikota. Dalam praktiknya, Pattiro Semarang menjembatani warga Tambakrejo untuk melakukan audiensi dengan pihak Pemerintah Kota Semarang. Hal tersebut sebagaiman yang disampaikan oleh Direktur Pattiro Semarang, Widi Nugroho:

Komunikasi awal dilakukan dengan walikota hasilnya positif di mana ada keinginan untuk mediasi. Pemetaan didapatkan walikota oke, kepala disperkim oke, sekda tidak, camat tidak, dan kekuatannya ada di walikota bilang oke untuk mediasi. $^{25}$

Organisasi masyarakat sipil lainnya yang tergabung dalam advokasi dan melakukan langkah politis yaitu Guyub TBRS. Guyub TBRS merupakan sebutan bagi mereka yang aktivis seni dilingkungan Taman Budaya Raden Saleh (TBRS) Semarang.

\footnotetext{
${ }^{25}$ Widi Nugroho, Direktur Pattiro Semarang, wawancara, 2 Januari 2020.
} 
Meskipun mereka memiliki organisasi formal yaitu Dewan Kesenian Kota Semarang (Dekase), namun mereka tidak menggunakan nama tersebut, karena organisasi tersebut bentukan pemerintah Kota Semarang. Organisasi tersebut memiliki kemampuan pendampingan kemanusiaan dan juga melalui kemampuan seni. Tahap awal pendampingan sebelum penggusuran upaya yang dilakukan yaitu pendampingan warga secara intensif dan pelaksanaan kampanye kreatif yang dilakukan bersama organisasi lainnya. Akan tetapi kondisi tersebut sudah tidak bisa dilakukan lagi ketika penggusuran paksa sudah terjadi, sehingga pembagian peran yang memiliki koneksi politik dilakukan oleh aktor Guyub TBRS.

Guyub TBRS dalam melaksanakan advokasi memiliki pembagian kerja, di mana ketika berkaitan dengan politik maka ada aktor yang memang memiliki jejaring. Melalui hasil wawancara yang dilakukan oleh penulis bahwasanya aktor di Guyub TBRS memiliki hubungan politik dengan Walikota Semarang yang diwakili oleh Jhonari dan Sunu, sedangkan dengan Gubernur Jawa Tengah diwakili oleh Kunut dan Daniel. Kedekatan tersebut salah satunya tercipta karena mereka menjadi tim pemenangan saat Pilkada. Meskipun Jhonari berasal dari Partai Rakyat Demokratik (PRD), namun saat Pemilu 2019, dirinya mencalonan diri untuk menjadi anggota legislatif melalui Partai Demokrasi Indonesia (PDI) Perjuangan, yang notabene juga partai Walikota Semarang berasal.

Aktivitas politis dapat dijelaskan saat terjadi penggusuran paksa, koalisi harus bertindak ada yang melakukan lobi ke pemerintah untuk penyelesaian masalah. Dengan demikian, Jhonari dan Sunu menemui Walikota Semarang untuk memberikan gambaran penyelesaian masalah. Melalui argumen untuk tidak memindahkan warga ke Rusunawa Kudu melainkan membangun pemukiman kampung deret yang akan dibangun di Kali Banger akan menjadi solusi bagi kedua belah pihak antara pemerintah dan warga Tambakrejo.

Pasca penggusuran langsung saya ke Tambakrejo dan mengirim foto ke walikota dan Pak Fajar yang sekarang ketua satpolPP. Kami juga memberi perspektif bahwa ini bisa diselesaikan tanpa konflik berkepanjangan. Pasca penggusuran saya melihat situasi lapangan untuk menjadi bahan loby. Waktu itu Pak Hendi kurang mengerti medannya atau lokasi detailnya, dan hanya dilaporin anak buahnya yang pokoknya selesai. Padahal dampak sosialnya mereka tidak pernah berpikir karena mereka hanya berpikir administratif. Dalam proses loby, saya 
selalu berargumentasi, bahwa tugas pemerintah menggusur tapi memberi rumah yang layak bagi warganya. ${ }^{26}$

Bagaimanapun juga, atas terjadinya penggusuran tersebut, tekanan kepada Walikota melalui media sosial sangat besar. Dengan adanya tekanan tersebut, Walikota meminta bantuan kepada Jhonari supaya masalah tidak berlarut. Dengan demikian momen tersebut digunakann oleh koalisi masyarakat sipil di satu sisi untuk memberikan solusi supaya warga dapat bertahan di dekat laut, dan di sisi lain membantu supaya masalah penggusuran tidak menjadi isu nasional.

Melalui pendekatan politik tersebut, koalisi masyarakat sipil berhasil untuk membantu advokasi warga. Pemangku kebijakan baik Walikota Gubernur, BBWS, Komnas HAM duduk bersama untuk membicarakan solusi pada 12 Mei 2019. Hasil yang didapatkan Pemerintah Kota Semarang menganggarkan untuk pembangunan kampung deret yang akan dikelola secara komunal, dan dalam masa tunggu pembangunan, BBWS bertangung jawab untuk membangunkan hunian sementara. Dalam bahasa lain kesepakatan yang dicapai pada Desember 2018 kembali harus dilaksanakan oleh seluruh pihak.

\section{Refleksi: Advokasi Kebijakan Sebagi Proses Politik}

Sebagaimana yang kita lihat dari diskusi di atas menunjukkan aktivitas advokasi yang dilakukan koalisi masyarakat sipil tidak terlepas dari relasi kuasa politik dengan pemangku kebijakan. Efektivitas dalam proses advokasi salah satunya melalui keahlian meyakinkan para pembuat kebijakan untuk mencapai tujuan kebijakan. Dalam konteks kebijakan, Risley menganggap hubungan masyarakat sipil dalam konteks kebijakan yaitu berkontribusi dalam debat kebijakan dan memengaruhi pengambilan keputusan. ${ }^{27}$

Kemampuan berelasi dengan aktor politik dari berbagai lini merupakan bagian yang penting dalam proses advokasi. Konteks advokasi di Tambakrejo, pemilihan strategi dengan cara dialog tanpa menggunakan kekerasan, merupakan langkah politis atas kondisi warga yang inferior. Pemilikan aset yang lemah, dapat dengan mudah pemeritah menggusurnya secara paksa, akan tetapi koalisi advokasi mampu memainkan

${ }^{26}$ Jhonari, Anggota Guyub TBRS, wawancara, 2 Januari 2020.

27 Amy Risley, Civil Society Organizations, Advocacy, and Policy Making in Latin American Democracies: Pathway to Participation (New York: Palgrave Macmillan, 2015). 
peran supaya warga tetap mendapatkan haknya. Kemampuan untuk meyakinkan para pembuat kebijakan untuk tidak menggusur warga Tambakrejo dapat dilihat dari aktivitas politik yang dilakukan oleh anggota koalisi, di mana Guyub TBRS mampu melakukan loby politik kepada Walikota Semarang secara langsung ketika kondisi genting penggusuran paksa sudah terjadi. Selain itu kemampuan LBH Semarang mendampingi warga dalam melakukan pelaporan ke Komnas HAM menjadi langkah politis menjadi penting, mengingat hal tersebut menjadi awal tercapainya kesepakatan damai. Di sisi lain Pattiro Semarang mampu mendampingi warga untuk melakukan audiensi dan melakukan pemetaan kekuatan di Pemerintah Kota Semarang.

Peran aktor advokasi untuk bermain jauh dalam relasi kuasa politik menjadi menarik dalam kasus Tambakrejo. Dalam proses advokasi, salah satu peran yang dilakukan oleh Guyub TBRS perlu dilihat sebagai kerangka relasi kuasa politik yang nyata. Aktor Guyub TBRS cukup berbeda dengan organisasi lainnya dalam proses advokasi. Keberadaanya, di satu sisi berada pada anggota koalisi masyarakat sipil, namun posisinya juga menjadi orang dekat pemangku kebijakan dengan menjadi tim pemenangan saat Pilkada. Akan tetapi kondisi demikian penting untuk mencapai tujuan advokasi. Pemerintah merasa tertekan dan mau diajak untuk berdialog merupakan keberhasilan koalisi melalui pendekatan politik dan kekuatan publik. Akan tetapi, peran dari aktor Guyub TBRS yang menjembatani atas tekanan pemerintah dan kemauan dari masyarakat sipil merupakan langkah politis.

Kondisi advokasi tersebut juga dapat dilihat menggunakan Advocacy Coalition Framework (ACF). Kerangka ACF digunakan untuk memahami perubahan kebijakan yang terjadi dalam kontek advokasi. Kerangka tersebut menggambarkan bahwa dalam subsistem kebijakan relasi kuasa itu terjadi antara dua koalisi yang berbeda yang saling memengaruhi untuk mengubah kebijakan sesuai keyakinannya. Dalam proses tersebut untuk mencapai kesepakatan terdapat aktor yaitu broker. Kondisi demikian dalam proses advokasi di Tambakrejo, koalisi masyarakat sipil harus berhadapan dengan pemerintah, baik Pemerintah Kota Semarang maupun dengan Pemerintah Pusat sebagai pemilik proyek pembangunan. Akan tetapi kemampuan koalisi masyarakat sipil dalam mengkonsolidasikan warga, menjalin hubungan baik dengan pemerintah, serta kemampuan meyakinkan pemerintah menjadikan koalisinya mampu untuk memengaruhi pemerintah untuk tidak melakukan penggusuran. Selain itu peran broker 
juga dapat dilihat langsung oleh aktor Guyub TBRS. Dalam posisi tersebut disatu sisi sebagai aktor masyarakat sipil yang melakukan advokasi warga Tambakrejo, di satu sisi memposisikan sebagai tim pemenangan Walikota saat Pilkada. Dari peran tersebut mampu memainkan peran broker dalam konteks ACF untuk menjembatani antara kehendak masyarakat sipil dan kehendak pemangku kebijakan untuk sampai pada titik sepakat. Hal tersebut dapat dilihat dari kembalinya ke kesepakatan damai pasca penggusuran paksa, pembangunan hunian sementara oleh BBWS, serta masuknya anggaran pembangunan kampung nelayan ke APBD Kota Semarang.

Advokasi secara koalisi mampu menjadi kekuatan dalam akumulasi sumber daya, namun kemampuan untuk manajemen sumberdaya dan merancang arah strategi harus dimiliki dalam koalisi. ${ }^{28}$ Melalui praktik advokasi di Tambakrejo, kemampuan mengelola sumberdaya dilakukan oleh masing-masing organisasi. Mereka mengambil peran dalam bidang yang mereka kuasai, seperti LBH Semarang melakukan Aksi Kamisan untuk menggalang masa, Guyub TBRS melakukan kampanye kreatif baik melalui film maupun kegiatan untuk memperingati hari penting seperti Hari Air, dan Hari Nelayan, serta melakukan pendekatan personal saat kondisi sedang genting. Di lain sisi, Pattiro Semarang membantu warga dalam memfasilitasi harapan dan membantu proses dialog dengan pemerintah. Ketika ditinjau dari sisi sumber daya, penelitian ACF setidaknya memiliki enam sumber daya. Akan tetapi, dari keenam sumber daya tersebut penelitian terdahulu menunjukkan kekuatan legal formal menjadi sumberdaya yang paling kuat. ${ }^{29}$ Namun dalam penelitian lainnya menganggap bahwa sumberdaya dari opini publik lebih kuat dibanding yang lain. ${ }^{30}$ Akan tetapi dalam penelitian bagaimanapun juga dalam konteks advokasi masyarakat sipil, opini publik masih dianggap kuat karena hal tersebut akan memberikan tekanan kepada pemerintah. Di sisi lain kemahiran kepemimpinan dalam masyarakat sipil juga kuat. Hal tersebut mengingat mampunya mereka berhadapan dan berhubungan baik dengan aktor politik karena kemampuan kepemimpinan dari masing-masing organisasi yang diturunkan dalam bentuk srategi.

\footnotetext{
${ }^{28}$ Margaret Levi and Gillian H. Murphy, Loc.Cit.

${ }^{29}$ Jonathan J. Pierce, Loc. Cit.

${ }^{30}$ Daniel Nohrstedt, Loc.Cit.
} 


\section{Kesimpulan}

Advokasi secara koalisi yang diterapkan terhadap kasus relokasi warga Tambakrejo memberi dampak positif pada aktivisme yang dilakukan. Terbentuknya koalisi mampu mengakumulasikan sumber daya antar organisasi. Hal tersebut berdampak terhadap munculnya berbagai macam strategi untuk mengubah kebijakan, mulai dari mengikat publik, mengikat pemerintah, kampanye informasi, dan monitoring kebijakan. Selain itu jaringan politik yang sudah dibangun oleh masing-masing organisasi sangat penting untuk mencapai tujuan advokasi dan menjalin hubungan komunikasi dengan pemangku kebijakan. Advokasi koalisi yang dilakukan oleh organisasi masarakat sipil di Kota Semarang memperlihatkan bahwasanya kebijakan harus dipandang sebagai produk politik bukan hanya saja antar aktor di pemerintahan namun aktor diluar pemerintah juga.

Bagaimanapun juga advokasi secara berkoalisi akan mengalami hambatan karena setiap organisasi yang tergabung memiliki perbedaan latar belakang. Aktor yang tergabung dalam advokasi juga memiliki beban kerja lain di organisasinya, baik kondisi tersebut menjadi pemicu dalam pengambilan keputusan. Kondisi demikian menjadi pengambilan keputusan tidak cepat mengingat tidak ada organisasi yang memiliki hak mutlak dalam pengambil keputusan dan semua keputusan untuk langkah advokasi harus didiskusikan dahulu dalam koalisi. Selain itu perbedaan model advokasi setiap organisasi, mempengaruhi gaya komunikasi publik sehingga dalam advokasi akan terjadi dialog antara warga dan pendamping dari berbagai latar belakang.

\section{DAFTAR PUSTAKA}

Badan Pusat Statistik Kota Semarang. Kecamatan Semarang Utara dalam Angka 2019. Kota Semarang: BPS, 2019.

Barkan, Steven E. "Interorganizational Conflict in the Southern Civil Rights Movement" dalam Sociological Inquiry. Vol. 56, No. 2 (1986), h. 190-209.

Bass, Garry D. "Advocacy in the Public Interset" dalam Essays on Excellence Lessons from the Georgetown Nonprofit Management Executive Certificate Program. Wasington D.C.: Gerogetown University, 2009.

Gamson, William A. "A Theory od Coalition Formation" dalam American Sociological Review, Vol. 26, No. 3 (1961), h. 373-382. 
Gen, Sheldon \& Amy C. Wreight. "Policy Advocacy Organizations: A Framework Linking Theory and Practice" dalam Journal of Policy Practice, Vol. 12, No.3 (2014), h. 163-193.

Kementerian Pekerjaan Umum dan Perumahan Rakyat/Balai Besar Wilayah Sungai Pemali-Juana Provinsi Jawa Tengah, Analisis Dampak Lingkungan Hidup (ANDAL) Rencana Pembangunan Pengendalian Banjir di Kanal Banjir Timur Kota Semarang, Provinsi Jawa Tengah. 2018.

Kementerian Perencanaan Pembangunan Nasional/Badan Perencanaan Pembangunan Nasional. Rencana Pembangunan Jangka Menengah Nasional (RPJMN) 20152019: Buku III Agenda Pembangunan Wilayah. Jakarta: BAPPENAS, 2015.

Levi, Margaret \& Gillian H. Murphy. "Coalition of Contention: The Case of the WTO Protest in Seattle" dalam Political Studies, Vol. 54 (2006), h. 651-670.

Nohrstedt, Daniel. "Shifting Resources and Venues Producing Policy Change in Contested Subsystems: A Case Study of Swedish Signals Intelligence Policy" dalam The Policy Studies Journal. Vol. 39, No. 3 (2011), h. 461-484.

Pierce, Jonathan J. "Advocacy Coalition Resources and Strategies in Colorado Hydraulic Fracturing Politics" dalam Society \& Natural Resources: An International Journal, Vol. 29, No.10 (2016), h. 1155-1168.

Prakash, Aseem \& Mary K. Gugerty (Eds.). Advocacy Organizations and Collective Action. New York: Cambridge University Press, 2010.

Reid, Elizabeth J. "Understanding the Word "Advocacy": Context and Use" dalam Elizabeth J. Reid (Eds.). Advocacy and the Policy Process: Structuring the Inquiry into Advocacy. Washington, D.C.: The Urban Institute, 2000.

Risley, Amy. Civil Society Organizations, Advocacy, and Policy Making in Latin American Democracies: Pathway to Participation. New York: Palgrave Macmillan, 2015.

Sabatier, Paul A. \& Christopher M. Weible. "The advocacy Coalition Framework Innovation and Clarifications" dalam Paul Sabatier (Eds.). Theories of the Policy Process. Boulder,CO: Westview Press, 2007.

Sewell, Granville C. "Actors, Coalitions, and the Framework Convention on Climate Change". Dissertasi. Massachutsetts: Massachusetts Institute of Technology, 2005.

Staggenborg, Suzanne. "Coalition Work in the Pro-Choice Movement: Organizational and Environmental Opportunitiesand Obstacles" dalam Social Problems, Vol. 33, No. 5 (1986), h. 374-390. 
Strolovitch, Dara Z. Affirmative Advocacy: Race, Class, and Gender in Interest Group Politics. Chicago: Univesity of Chicago Press, 2007.

Weible, Christopher M. \& Paul A. Sabatier, " Panduan Kerangka Koalisi Advokasi" dalam Frank Fischer, Gerald J. Miller \& Mara S. Sidney (Eds.). Handbook Analisis Kebijakan Publik:Teori,Politik dan Metode. Bandung: Nusamedia, 2016.

------..,dkk. "A Quarter Century of the Advocacy Coalition Framework: An Introduction to the Special Issue" dalam The Policy Studies Journal. Vol. 39, No. 3 (2011), h. 349-360.

------, Paul A. Sabatier \& McQueen "Themes and Variations: Taking Stock of the Advocacy Coalition Framework" dalam The Policy Studies Journal. Vol. 37, No. 1 (2009), h. 121-140.

Zompetti, Joseph P. "The Role of Advocacy in Civil Society" dalam Argumentation: An International Journal of Reasoning, Vol. 20 (2006), h. 167-183.

\section{Wawancara}

Jhonari, Anggota Guyub TBRS, wawancara, 2 Januari 2020.

Widi Nugroho, Direktur Pattiro Semarang, wawancara, 2 Januari 2020. 